\title{
Self-control and Pornography Behavior among Junior High School Student
}

\author{
Rika Hardani, Dwi Hastuti, Lilik Noor Yuliati \\ Departement of Family and Consumer Sciences \\ Institut Pertanian Bogor, IPB \\ Bogor, Indonesia \\ rika-hardani@ipb.ac.id
}

\begin{abstract}
Pornography
behavior

by

adolescents, tends to increase. This research aimed to study the influence of adolescence's self-control on the pornography behavior. The study used a cross-sectional research design. Respondents who qualify as many as 278 boys and 322 girls. Multiple linear regression tests applied to check the effect of self-control on the pornography behavior. Result demonstrated a significant and negative correlation between selfcontrol and pornography behavior. Variable self-control also showed its influence to decrease pornography behavior. Selfcontrol is the ability of people to protect themselves from something that is not good. The self-control in adolescence, can decrease the behavior of pornography.
\end{abstract}

Keywords: self-control; pornography behavior; junior high school student

\section{INTRODUCTION}

The behavior of pornography done by adolescents tends to increase from year to year. Advances in technology made many changes in society. Brofenbrenner [1], environment condition will impact on the development of a child. Technological advances can led to the behavior of internet pornography who do adolescents. Seto et al.[13] the phenomenon of pornography is a result of the rapid development of technology such as the internet. The behavior of watching pornography, in a prolonged period of time, it will be ever-increasing frequency, so that it could lead to various problems on the behavior of adolescents. Luder et.al [9] problems that can arise due to the high intensity of watching pornography including doing free sex, sexual violence, the decline in academic achievement, addiction to pornography, sex orientation disorders. D'Orlando [5], if not stop immediately, it will be able to bring up a more severe wrong behavior such as sexual violence, aberrant sexual orientation, romantic life as adults that can even be fatal as the killer becomes sex passion driven unfulfilled and distorted. Much of the ease with which accepted girls, in fact, most such facilities comes from their own parents see Weber et al. [16]. Ease of access porn content in social media via gadgets (mobile, video, internet) obtained at too early an age without being given proper rules in its use, it can be one of the causes of the behaviors of pornography, see Romito \& Beltamini [11].

Children must have a resistance to counteract these negative things. The ability to control them is something very important. Self-control is the ability of individuals to protect themselves from something that is not good and able to do better for their future, see De Ridder et al., [4]. In line with research Romito and Beltramini [11] that the boys more exposed to pornography than girls. Boys are significant than girls to say they view pornography because they like it and because it is something interesting. The existence of good selfcontrol in adolescence will prevent adolescence from negative behaviors such as pornography. This study examines the role of self-control in the pornography behavior.

At this time a lot of research on the behavior of pornography done by adolescents. Romito \& Beltramini [11] explain ease of access porn content in social media via gadgets (mobile, video, internet) obtained at too early an age without being given proper rules in its use, it can be one of the causes of the behaviors of pornography. This research is good at finding the cause of the occurrence of the behavior of pornography. But there are some issues on how to prevent pornography by adolescents. Research in China by Cheung and Cheung [3] getting results that self-control is low associated with delinquency. Researchers also found that the low level of self-control is also associated with negative social conditions in China, including the destruction of adolescent social bond, a rogue group of deviant behavior, education, underachievement, parents forced the school experience, negative relationships with peers, life events are full of stress, and labeling by parents and teachers.

Considering the importance of finding solutions to the behavior of adolescent pornography, this study aims to see the influence of self-control in reducing the behavior of adolescent pornography. This study used questionnaires to retrieve data and used research design cross-sectional study. This prior research had found some pornography causes of behavior, but has yet to discuss how to prevent the behavior of pornography 


\section{METHOD}

The study used cross-sectional study that the research carried out at a particular time. The study was conducted in four Junior High School in South Tangerang, Indonesia. Respondents were taken in this study is a junior high school student. In South Tangerang, the number of internet users is relatively high. Sampling was done by purposive school based on the recommendation of the Department of Education of South Tangerang, Indonesia, with criteria that the students come from different school conditions and economically diverse backgrounds, in order to describe a variety of conditions. From the school obtained, randomization by simple random sampling technique with the class as a cluster, making it easier to capture data. The total population of the four schools in 1750 students, taken into 17 classes. Respondents who qualify as many as 278 boys and 322 girls.

Data is collected by self-report, respondents fill in questionnaires given. Data for self-control using the SelfScoring Self-Control Scale by Tangney et al.[15] modified by Cronbach Alpha 0.80. The scale used is a Likert scale of 1-4 $(1=$ strongly disagree, $2=$ disagree, $3=$ agree, $4=$ strongly agree). Pornography Adolescent Behavior questionnaire with Cronbach Alpha value of 0.70, with a Likert scale of 1-3 (1= never, 2 = rarely, 3 = frequently). The data analysis using Microsoft Excel and SPSS for windows. Pearson correlation test was conducted to examine the relationship of self-control with the pornography behavior. Multiple linear regression tests conducted to examine the effect of self-control on the pornography behavior. The categorization of all variables using an index value of each variable, based on standard normative values with high cut-off points $(>80.0)$, moderate (60.0-80.0) and low $(<60.0)$ see Pasaribu et al. [10]

\section{RESULTS}

\section{A. Characteristics of Families}

The study found the average age of father is 44.9 years old and mother's average age 41.9 years old. Parental age range are on the middle adulthood. Santrock [12], in this age range generally parents are in stable condition, both economically and emotionally. The father who got undergraduate education as much as 11.3 percent and most of the mother's education $(34.0 \%)$ is high school. Formal education of parents describe the majority of parents have sufficient knowledge. Most of the sample $(67.5 \%)$ had a number of families of 5-7 people and most of them $(45.2 \%)$ had a father who worked as a private employee. Most of the mother $(62.7 \%)$ were housewives. The study found the number of parental income are very diverse. Most of the family (29.7\%) had an income amounting to 1, $000001 \mathrm{Idr}$ up to $3000000 \mathrm{Idr}$. As much as 22.5 percent of the family have an income $3000001 \mathrm{Idr}$ until $5000000 \mathrm{Idr}$. The family which had incomes above $11000000 \mathrm{Idr}$ as much as 16.5 percent. The distribution of parental income of example looks very diverse.

\section{B. Characteristics of Samples}

The study involved 600 respondents consisting of 278 boys $(46.3 \%)$ and 322 girls $(53.7 \%)$. The research found that the age range of participants from 12 to 16 with an average was 13.4 years old.

\section{Figures and Tables}

Tangney et al. [14], self-control is the ability to refrain from doing negative things and pushing yourself to do positive things. In Table 1 the results showed that about 57.8 percent participant have self-control score above 60 point included in the category of medium and high.

TABLE I. DISTRIBUTION OF SAMPLE BASED ON SELFCONTROL

\begin{tabular}{|c|c|}
\hline \multirow{2}{*}{ Variable } & $\begin{array}{c}\text { Distribution of Sample Based on } \\
\text { Self-Control }\end{array}$ \\
\cline { 2 - 2 } & Self-Control \\
\hline Categories & Percentage $(\%)$ \\
\hline Low $(<60)$ & 42.2 \\
\hline Medium (60-80) & 45.5 \\
\hline High (>80) & 12.3 \\
\hline $\begin{array}{c}\text { Mean } \pm \text { Standard } \\
\text { deviation }\end{array}$ & $62.9 \pm 14.2$ \\
\hline Minimum-maximum & $17.9-100$ \\
\hline
\end{tabular}

The average score of self-control girls (37.9) is slightly higher than boys (37.2). There is not seen any statistically significant difference between boys and girls ( $p$-value $=0,14$ ). In line with the research Cheung and Cheung [3] in China that self-control girls are higher than boys. Most of the participants $(67.1 \%)$ in this study strive to achieve their goals. It shows that they have the self-control to be able to push themselves to do things well. Just a few children (12.0\%) who find difficult to stop the bad habit. Often participants act without thinking of the consequences $(18.8 \%)$.

\section{Pornography Behavior}

Pornography is pictures, sketches, illustrations, photographs, text, voice, sound, moving image, animation, cartoon, conversations, gestures, or any other form of messaging through various forms of media communication and/or performing in public, which contains obscenity or sexual exploitation violates the norms of morality in society, see Kementerian Agama RI [8]. The behavior of the pornography has not been up on stage doing the behavior of free sex.

Pornography behavior in the form of online viewing is asked in a questionnaire with questions for example "I opened a website porn every day"; "I play games with no scenes showing intimate body parts. Pornography behavior offline strives known through questions such as: "My friend forced me to read pornographic comics". The form of questions to 
determine whether the children saying or hearing things that are pornographic, for example: " I seduce my girlfriend via phone or skype ".

The results showed a statistically significant difference in the behavior of pornography between boys and girls $(\mathrm{p}=$ $0.03)$. In boys, the majority $(95.7 \%)$ had a pornographic behavior in the low category. Girls are also the majority $(97.8 \%)$ had a lower category pornographic behavior. In girls, the percentage of children belonging to the category of low, much more. The boy who had seen porn sites every day $(23.4 \%)$ more than girls $(5.3 \%)$. The duration of the child sees porn games also vary. There are children see porn games for two hours a day (38.6\%) and who view pornographic websites for less than an hour each day there was as much as 23.2 percent.

\section{E. Self-Control and Pornography Behavior}

Hofmann et al. [7], self-control is the ability of individuals to exercise restraint or direct themselves toward better when faced with temptations. Pearson correlation analysis was shown to result in the significant negative relationship between self-control with pornographic behavior $(\mathrm{r}=-0.71 * *, \mathrm{p}<0.05)$. Variable self-control also showed the influence of self-control variables on the behavior of pornography by 50 percent.

\section{DISCUSSION}

Research shows that high self-control also relates to an adjustment for a better self (including depletion of psychopathology,and increasing self-esteem), contribute to the success of the academic field, reduce overeating, reducing alcohol abuse, have a better relationship, and have good interpersonal skills,see Tangney etal.[15]. Self- control allows humans to live and work together in a cultural system that could benefit many parties, and many other positive benefits. Generally, it can be concluded that self-control is concerned with how individuals control their emotions and impulses from within himself so able to make decisions and take effective action in accordance with the standards of the ideal, moral values and social expectations, see De Ridder et al. [4].

The result showed statistically significant differences in on conduct pornography between boys and girls. The children in research show pornography behavior in the low category. Girls who are the low category, there are more. In research Weber et al. [16] also found that the difference between the boys and girls in seeing pornography. Experiments inspecting about pornography found that more boys like it. One reason why men more like pornography is men has an organ which producing hormone testosterone. Women producing testosterone but not as much as a man. Testosterone affects the brain. Men do have testosterone since he was still in his mother's womb. Chromosomes from men, producing two "bursts" of testosterone. This triggers changes in the brain and body. "Bursts" The effect on the male brain. Men were more interested in objects, actions, and competition than women. Testosterone is located on the left (parietal) lobe helps him visualize objects in 3 dimensions (both when watching a football game or see a woman across the street), see Stambaugh [14].

Bronfenbrenner [1] ecology theory states that individual development cannot be separated from the context of the environment be the individual is part of a comprehensive system (family, community, society, and others). Children easily imitate the behavior of those around him. Children will easily imitate good behavior, when people are near the child shows good behavior consistently. Currently, the good or bad behavior can also be imitated by children through electronic media such as television or the Internet. The children really need to be protected the bad environment, and children should be able to filter good or bad thing.

The results of research on self-control variable with pornography showed a statistically significant negative. The higher of self-control in boys and girls, it tends to decrease pornographic behavior. In line with research Cheung and Cheung [3] showed that low self-control related to delinquency. Researchers also found that low self-control is also linked to social conditions negatively Chinese teenager, including damage to the attachment of social (social bond), a group of naughty children, deviant behavior, educational under-achievement, parental force, school experiences were negative, negative relationship with colleagues, stressful life events, and labeling by parents and teachers. Boman et al. [2] showed that low self-control related to delinquency. Conditions families who carry out their functions properly, such as health and well-being will affect the behavior of adolescents, see Williams and Anthony [17]. Research Gault and Sherman [6] found that the evidence strongly suggests that the relationship interplay between parental attachment with the behavior of juvenile delinquency.

\section{CONCLUSION}

This study showed the influence of self-control variables on the behavior of pornography. This study shows that good self-control at will, will be able to decrease the behavior of pornography. The task of parents and teachers and government to create a good environment for the development of selfcontrol of children: 1) Establish a close relationship and good communication with teenagers. It is expected to form a good self-control in adolescents. This program such as making a regular activities every week to do leisure and intimate activities with children, such as swimming together, or going to the park with children; 2)Parents need to encourage children to follow extracurricular activities after school hours. Positive forms of activities such as sports, arts, nature lovers and so on, can train children to refrain or reject bad things. This selfcontrol ability needs to be taught to children since childhood by parents and teachers.

Some suggestions for the teacher are 1) teacher creates a character building activity program for children to establish a good self-control; and 2) prohibit children from bringing hand phone to school. For the purpose of contacting parents, can use the school phone. 
Some suggestions for government: First, create a special program on the guidance of good behavior on students and put into compulsory subjects, for example, provide about 15 minutes each morning before starting regular lessons for character building materials; and Second, regular and rigorous examination of books that are used as guidance in teaching in schools, both printed and electronic versions by the Ministry of National Education. Do not let the books referred to as teaching, does not contain pornographic material content or any other negative behavior.

\section{REFERENCES}

[1] Bronfenbrenner, U. Ecological models of human development. In International Encyclopesia of Education: Elsevier, 1994.

[2] Boman, J.H., Krohn, M.D., Gibson, C.L., Stogner, J.M. Investigating friendship quality: An exploration of self-control and social control theories' friendship hypotheses. (Journal of Youth and Adolescence, 41(11), 1526-40. Doi:http://dx. Doi. Org / 10.1007/ s10964-012-9747-x. 2012)

[3] Cheung, N.W.T., \& Cheung, Y.W. Self-control, social factors, and delinquency: A test of the general theory of crime among adolescents in hong kong. (Journal of Youth and Adolescence, 37(4), 412- 430. Doi :http : // dx . doi . org /10 .1007 / s10964-007-9218-y, 2008

[4] De Ridder, D.T., de Boer, B.J., Lugtig, P., Bakker, A.B.,vanHoof,E.A.Not doing bad hings is not equivalent to doing the right thing:Distiguish between inhibitory and initiatory self-control. Elsevier Ltd doi : 10.1016.W.W, 2011.

[5] D'orlando, F.The demand for pornography. Journal of Happiness Studies, 12(1), 51-7. doi:http:// dx.doi .org/ 10.1007/ s10902-009-91750. 2011

[6] Gault-sherman, M. It's a two-way street: The bidirectional relationship between parenting and delinquency. (Journal of Youth and Adolescence, 41(2), 121-45. Doi :http:// dx. doi. Org / 10.1007/ s10964$011-9656-4,2012$.

[7] Hofmann, W., Baumeister, R. F., Förster, G., \& Vohs, K. D. Everyday temptations: an experience sampling study of desire, conflict, and self- control. (Journal of personality and social psychology, 102(6), 1318, 2012).

[8] Kementrian Komunikasi dan Informatika RI. Pengguna Internet di Indonesia Capai 82 juta. https://kominfo.go.id, 2008.

[9] Luder, M., Pittet, I., Berchtold, A., Akré, C., Michaud, P., Surís, J. Assocoations between online pornography and sexual behavior adolescents: myth or reality? Archieves of Sexual Behavior, 40(5), 1027 - 1035 .doi: http://dx.doi.org/10.1007/s10508-010-9714-0,2011.

[10] Pasaribu R, Hastuti D, Alfiasari A. Gaya Pengasuhan Permisif dan Rendahnya Sosialisasi Nilai dalam Keluarga Berisiko terhadap Penurunan Karakter Remaja.. (Jurnal Ilmu Keluarga Dan Konsumen, 6(3). Retrieved from http : // journal . ipb . ac . id / index . php / jikk / article /view/ 9984/ 7806, 2015

[11] Romito, P., \& Beltramini, L. (2015). Factors associated with exposure to violent or degrading pornography among high school students. (The

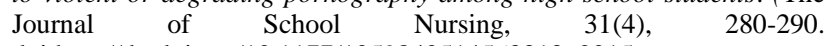
doi:http://dx.doi.org/10.1177/1059840514563313,2015.

[12] Santrock, J.W. (2011). Life-Span Development: Thirteenth Edition. ( McGraw-Hill, New York, 2011.

[13] Seto, M.C., Hermann, C.A., Kjellgren, C., Priebe, G., Svedin, C.G., Långström, N. Viewing child pornography: Prevalence and correlates in a representative community sample of young swedish men. (Archives of Sexual Behavior, 44(1), 67-79. doi:http://dx.doi.org/10.1007/s10508013-0244-4, 2015)

[14] Stambaugh, R. Why Men Like Porn. (http: //www. Webmd .com/sexrelationships/ features / why- men-like-porn,2011

[15] Tangney J., Baumeister RF, Boone AL. High self-control predicts good adjustment, less pathology, better grades, and interpersonal success. (Journal of personality, 72, 271-324, 2004

[16] Weber, M., Quiring, O., Daschmann, G. (2012). Peers, parents and pornography: Exploring adolescents' exposure to sexually explicit material and its developmental correlates. (Sexuality \& Culture, 16(4), 408-427. doi: http:// dx. doi.org/ 10.1007/ s12119-012-9132-7, 2012

[17] Williams, L.R., Anthony, E.K. A model of positive family and peer relationships on adolescent functioning. Journal of Child and Family (Studies, 24(3), 658-667. Doi :http: //dx. doi. org/ 10.1007/ s10826-0139876-1, 2015J. Clerk Maxwell, A Treatise on Electricity and Magnetism, 3rd ed., vol. 2. Oxford: Clarendon, 1892, pp.68-73. 